\title{
Licensing Arrangements and the Development of the Solar Energy Industry
}

Michael Green
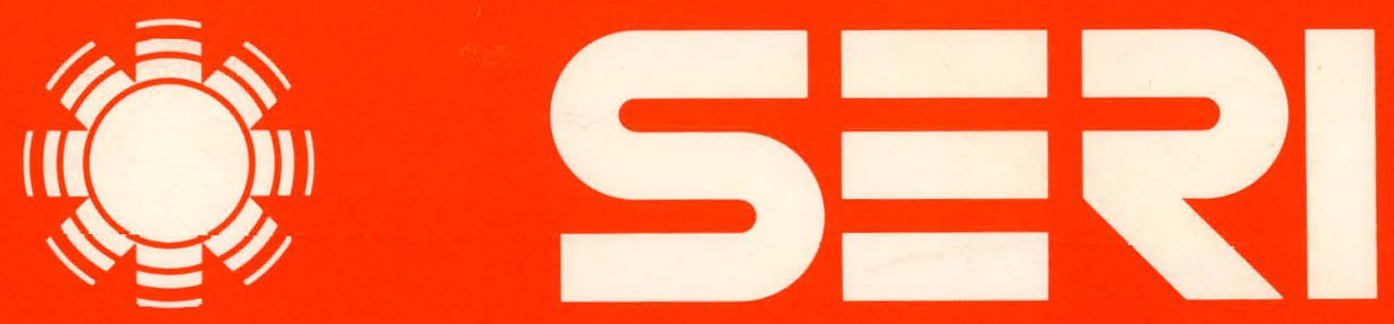

Solar Energy Research Institute A Division of Midwest Researchi Institute

1536 Cole Boulevard

Golden, Colorado 80401

Operated for the

U.S. Department of Energy under Contract No. EG-77-C-01-4042

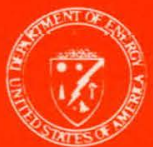




\section{DISCLAIMER}

This report was prepared as an account of work sponsored by an agency of the United States Government. Neither the United States Government nor any agency Thereof, nor any of their employees, makes any warranty, express or implied, or assumes any legal liability or responsibility for the accuracy, completeness, or usefulness of any information, apparatus, product, or process disclosed, or represents that its use would not infringe privately owned rights. Reference herein to any specific commercial product, process, or service by trade name, trademark, manufacturer, or otherwise does not necessarily constitute or imply its endorsement, recommendation, or favoring by the United States Government or any agency thereof. The views and opinions of authors expressed herein do not necessarily state or reflect those of the United States Government or any agency thereof. 


\section{DISCLAIMER}

Portions of this document may be illegible in electronic image products. Images are produced from the best available original document. 
Printed in the Uniled States of America

Available from:

National Technical Information Service

U.S. Department of Commerce

5285 Port Royal Road

Springfield, VA 22161

Price:

Microfiche $\$ 3.00$

Printed Copy $\$ 4.50$

\section{NOTICE}

This report was prepared as an account of work sponsored by the United States Govcrnment. Neither the United States nor the United States Department of Energy, nor any of their employees, nor any of their contractors, subcontractors, or their employees, makes any warranty, express or implied, or assumes any legal liability or responsibility for the accuracy, completeness or usefulness of any information, apparatus, product or process disclosed, or represents that its use would not infringe privately owned rights. 
SERI /TR-62-260

UC CATEGORY: UC $-59,60,61,62,63,64$

LICENSING ARRANGEMENTS AND THE DEVELOPMENT OF THE SOLAR

ENERGY INDUSTRY

MI CHAEL GREEN

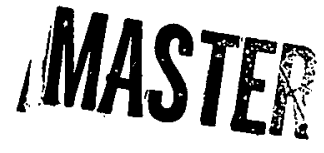

JUNE 1979

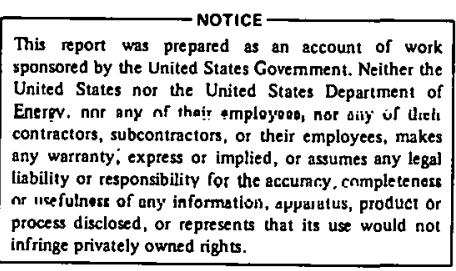

$\cdots$

Solar Energy Research Institute

1536 Cole Boulevard

Golden, Colorado 80401

A Division of Midwest Research Institute

Prepared for the

U.S. Department of Energy

Contract No. EG $\cdot 77 \cdot C \cdot 01 \cdot 4042$ 


\section{FOREWORD}

This paper on licensing arrangements and the development of the solar energy industry was prepared by the Solar Energy Research Institute (SERI) to fulfill, in part, SERI's solar information dissemination function. The paper is part of the Market Development Branch Law Program, which in turn is part of the overall program of the Technology Commercialization Division.

This is the second of eight 1978 Summer Law Intern Papers sponsored by the SERI Law Program. The other seven address (1) the impact of the antitrust laws on the commercialization of solar heating and cooling, (2) problems in the administration of state solar legislation, (3) legal and institutional implications of providing financial incentives to encourage the development of solar energy technologies, (4) legal considerations in the development and implementation of biomass energy technologies, (5) state approaches to solar energy incentives, (6) land-use barriers and incentives to the use of solar energy, and (7) utility rates and service policies as potential barriers to the market penetration of decentralized solar technologies. These eight studies are meant to raise and discuss the primary legal issues that are, or will be, generated by the commercialization of solar technologies.

The author of this paper, Michael Green, was a student at the University of Denver Law School while he was participating in the 1978 Summer Law Intern Program. He is now a third-year law student at the Yale Law School.

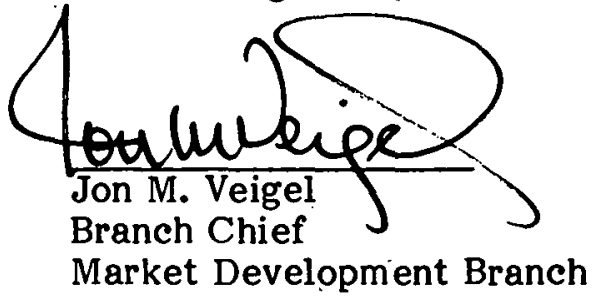

Approved for:

SOLAR ENERGY RESEARCH INSTITUTE

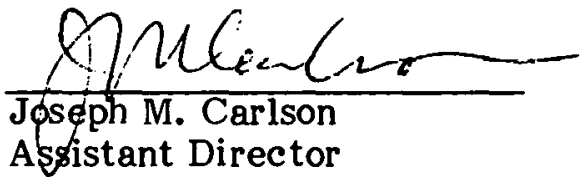

Technology Commercialization Division 


\section{SUMMARY}

This paper explores the process by which technology and information related to technology are transferred within industry. Property rights in technology are part of the broader field of intellectual property. The paper begins by exploring the general contours of legal protection for knowledge. The four basic forms of intellectual property-patents, trade secrets (or know-how), trademarks, and copyrights-are covered in varying degrees of depth, depending on their relative applicability to the development of the solar industry.

Once this background has been established, the legal aspects of licensing are examined. A license is a legal arrangement whereby a party (licensor) who controls the right to use an idea, invention, etc. shares the right to use the particular intellectual property with someone else (licensee). The complexity is generated by the intangible nature of the subject matter of the arrangement.

The paper then proceeds to describe the advantages and disadvantages of licensing from the point of view of potential licensees and licensors. For example, licensing a patented invention to a company that will manufacture and sell it as a product would produce royalty income for an inventor who might not otherwtse be able to market his idea; at the same time, licensing creates a competitor in a field in which the inventor previously held a monopoly.

Society as a whole often stands to benefit from licensing, because licensing creates greater efficiencies and increases the number of goods produced. Sometimes licensing is the only means by which a useful innovation can reach the marketplace. However, substantial barriers impede the full utilization of licensing.

Some of these barriers are closely related to the sizes of the enterprises involved. Thus, private inventors and small companies of ten lack the experience and knowledge to engage in the licensing process. Large firms, on the other hand, tend to prefer to exploit their own ideas, or those produced by corporations of equivalent size. These barriers may be especially significant for the solar industry, in which so many small actors are involved.

Generally, some barriers to the licensing process are understandable within a free market economy, taking into account the difficulty of sorting out useful innovation from impractical schemes. However, the imperatives of the energy crisis may call for a different calculus, in which the need to evolve alternative sources quickly justifies extra efforts to expedite the licensing process. A program, which could be operated by SERI, another government agency, or an intra-industry body, might provide information about licensing to relevant actors in the solar industry. Such a program's functions could range from providing basic information about licensing and marketing technology, to providing more detailed consultation services, to a systematic attempt to establish channels of communication between potential licensors and licensees. Any efforts made, would be an improvement over the haphazard situation existing at present, and the public would be rewarded with a healthier, more productive solar industry. 


\section{TABLE OF CONTENTS}

1.0 Introduction

2.0 Legal Protection of Intellectual Property

2.1 Patents

2.2 Trademarks

2.3 Trade Secrets and Know-How

2.4 Copyright Law

3.0 Licensing of Industrial Property

3.1 Legal Aspects

3.2 Advantages and Disadvantages of Licensing

4.0 Barriers to Licensing

5.0 Conclusions and Recommendations

6.0 References 


\section{SECTION 1.0}

\section{INTRODUCTION}

This paper discusses the transfer of industrially useful knowledge about solar energy from whoever owns or controls that knowledge to whoever is best suited to turn it into a marketable commodity. This field of law, involving what is known as "intellectual property," is complex and highly specialized-as much of a mystery to most lawyers as it is to most lay persons. Furthermore, solar technology is, itself, a broad, technically complex subject. The term solar implies a variety of technologies, including heating and cooling for buildings, photovoltaics (direct conversion of sunlight into electricity), biomass conversion, wind energy, ocean thermal conversion, solar thermal conversion, industrial process heat, and other applications [1]. Each of these technologies is at a different stage of development, with different implications as far as the law of intellectual property is concerned.

The actors involved in the solar industry are another source of complexity: "Participants in the emerging solar energy industry run the gamut from small firms with a handful of people to multinational giants" [2]. Extensive government involvement in research, which is mandated by law [3], introduces another set of factors into the technology marketplace.

The body of this paper is divided into three sections, with recommendations for future study and action appended at the end. The first section is a general discussion of intellectual property law. Naturally, there is some emphasis on possible applications to the emerging solar technologies. The next section discusses the licensing process and is itself divided into two parts. First, the legal aspects of licensing are treated. This first part of Section 3.0, like the preceding discussion of intellectual property in Section 2.0, is rather technical. The second part of Section 3.0 is a general discussion of the practical advantages and disadvantages of licensing. The major factors that might enter into a decision about involvement in a licensing arrangement are explored.

Section 4.0 examines current barriers to the licensing process. In an industry with many individual inventors and small businesses, the danger of technology underutilization is especially grave. Although licensing can provide for an efficient flow of knowledge from those who invent to those who are able to produce and market goods, substantial obstacles of ten stand in the way of the licensing process. These obstacles of ten include unrealistic attitudes on the part of inventors, resistance to new ideas among established enterprises, lack of knowledge about licensing among most people, and the absence of organized channels for communication between potential participants in licensing arrangements.

Finally, this analysis of barriers to licensing as a means of promoting solar technology commercialization, provides the basis for recommendations designed to facilitate licensing activity, thereby accelerating the growth of solar energy as a major antidote to the worsening energy crisis. 
SEPI 


\section{SECTION 2.0}

\section{LEGAL PROTECTION OF INTELLECTUAL PROPERTY}

Under certain circumstances, solar knowledge may be considered property which a person may own, exploit, and exclude others from using. There are four principal kinds of protection available for intellectual property: patents, trademarks, copyrights, and trade secrets. Licensing provides the means for the owner of an interest in intellectual property to give another person permission to operate within legally protected boundaries, under terms satisfactory to both parties. Thus, it is impossible to understand licensing without at least a rudimentary understanding of the natures of the various forms of intellectual property.

\subsection{PATENTS}

Patents have been defined as "...the legal mechanisms with which an inventor or a corporation can protect the investment in time, money, effort, and other resources expended in order to create a new contribution to technology. .." [4]. Patents consist of the right to exclude anyone else from making, using, or selling the patented invention for a period of 17 years [5]. Patent rights are creatures of federal law and are regulated in considerable detail by Title 35 of the United States Code, as well as by the rules of the Patent and Trademark Office [6]. Authority to develop the patent system is found in the United States Constitution, which provides that "Congress shall have the power. . .to promote the Progress of Science and useful Arts, by securing for limited Times to Authors and Inventors the exclusive Right to their respective Writings and Discoveries" [7]. 1

A solar invention would seek a patent by filing an application with the United States Patent and Trademark Office, which is within the Department of Commerce. The application must include: a complete description of the invention, sufficiently detailed and clear "as to enable any person skilled in the art to which it pertains or with which it is most nearly connected, to make and use the same" [8]; claims which define the subject matter of the invention [9]; drawings of the invention where its nature permits explication by drawing [10]; an oath or declaration that the applicant is the inventor [11]; and a filing fee [12]. The information divulged in the patent application is made public if and when a patent is granted. Obtaining a patent is thus a tradeoff: the inventor places knowledge in the public domain, and the public grants the inventor a 17-year monopoly.

Initial determinations of patentability are made by patent examiners after a search through relevant, prior U.S. and foreign patents and technical publications. If the decision is unfavorable, the applicant may appeal to the United States Patent Office, Board of Appeals, a judicial type of body within the Patent Office, and if necessary, to either the United States Court of Customs and Patent Appeals or to the United States District Court for the District of Columbia.

The basic requirements for patentability are set out in a statute: "Whoever invests or discovers any new and useful process, machine, manufacture, or composition of matter, or any new and useful improvement thereof, may obtain a patent therefore, subject to the conditions and requirements of this title" [13]. Thus, for a patent to issue, there must be an invention or discovery, and it must be new and useful [14]. Defining exactly what constitutes an invention has proven difficult. In Hotchkiss v. Greenwood [15], decided in 1850, the Supreme Court shed some light on the subject: 
Unless more ingenuity and skill. . .were required. . .than were possessed by an ordinary mechanic acquainted with the business, there was an absence of that degree of skill and ingenuity which constitute essential elements of every invention. In other words, the improvement is the work of the skillful mechanic, not that of the inventor. [16]

The Hotchkiss test was later refined into the "obviousness standard":

But all improvement is not invention, and entitled to protection as such. Thus to entitle it, it must be the product of some exercise of inventive faculties, and it must involve something more than what is obvious to a person skilled in the art to which it relates. [17]

In 1941, what may have originated as a mere rhetorical flourish by Justice Douglass seemed to establish a new, stricter standard:

Innfer the statute. . .the device must not only be "new and useful," it must also be an "invention" or "discovery." Since Hotchkiss, it has been recognized that if an improvement is to obtain the privileged position of a patent, more ingenuity must be involved than the work of a mechanic skilled in the art .... That is to say, the device, however useful it may be, must reveal the flash of creative genius, not merely the skill of the calling. [18]

For several years, there was confusion among the lower courts about the meaning and implications of the "flash of creative genius" language. Finally, in 1952 Congress attempted to clarify the situation by adding the following provision to the patent laws:

A patent may not be obtained... if the differences between the subject matter sought to be patented and the prior art are such that the subject matter as a whole would have been obvious at the time the invention was made to a person having ordinary skill in the art to which said subject matter pertains. Patentability shall not be negated by the manner in which invention was made. [19]

The first sentence of the language merely codified the existing "obviousness" standard. The second sentence of the language eliminated literal interpretations of the "flash of creative genius" language. Thus, there are now three patentability requirements: novelty, utility, and nonobviousness [20] .

Section 102 of the patent statute [21] clarifies some of the conditions for meeting the novelty requirement and provides for loss of the right to patent under certain circumstances. According to this section, a patent is obtainable unless: (1) prior to its invention by the applicant, it has been known and used in the United States or patented or described in a printed publication in this or a foreign country; (2) the invention was used in this country, or patented or published in this or a foreign country, more than one year before the application for a patent was submitted; (3) the applicant has abandoned the invention; (4) the inventor or his or her assigns has a patent on the invention in a foreign country, for which the inventor had applied more than 12 months before applying in the United States; (5) the invention was already described in a patent granted in the United States prior to its invention by the applicant; (6) the applicant did not actually invent the subject matter sought to be patented; or (7) someone else had already made the invention before the applicant, and that person had neither abandoned, suppressed, nor concealed the invention. Section 102 (g) also provides that in determining priority, 
the factors to be considered include date of conception, date of reduction to practice, and reasonable diligence of one who conceived the invention first but did not reduce it to practice. Under these rules, proving dates of conception and reduction to practice, diligence, and nonabandonment are essential. Accordingly, inventors should keep thorough logs or journals witnessed by persons who understand the subject matter therein [22].

Any other person who makes, uses, or sells a patented invention (without authorization) is an infringer [23], and the patent owner may obtain damages or an injunction against such injuries [24]. Invalidity of the patent may be pleaded as a defense to an infringement suit, as may noninfringement, absence of liability for infringement, and unenforceability [25]. There is much litigation over the validity of patents.

The law of patents allows existence of what can be termed dominant or "blocking" patents. Imagine, for example, that $A$ has invented and patented a stove that burns home refuse, and that $B$ later invents and patents a generator for use with A's stove. During the life of A's patent, B's patent is useless unless he obtains A's permission to exploit the basic stove patent. Meanwhile, A may manufacture stoves, but he may not attach generators to them without B's permission. A's patent is said to block B's patent. Either party could, of course, buy the other's patent outright. Alternatively, they could grant each other licenses to use their respective patent rights, which is called "crosslicensing."

Since their inception, patents have been the subject of controversy. One recurring criticism of the system is that it conflicts with the public policy against monopolies. Patents are also frequently criticized for giving too little protection. Indeed, there is much skepticism within the solar industry as to the usefulness of the patent system, particularly among small businesses. The president of one growing firm commented to me that he "wouldn't give a nickel for all the patents in the solar industry." While some skepticism might be justified, there is also much to be said for the benefits afforded by patents, particularly to smaller enterprises. The tendency to downgrade the value of patent protection stems from two sources: (1) the ability to "invent around" patents and thereby render them worthless; and (2) the apparent hostility in the courts towards patents.

The first of these problems is a real one, but its significance may be exaggerated. A competitor of a patent holder may produce a device that accomplishes the same purpose as the patented product, and yet that is sufficiently different as not to infringe the patent. Large corporations are aware of this possibility and frequently develop entire portfolios of patents covering a range of processes similar to the patented invention. Thus, when DuPont developed nylon,

they did not rest content with patenting the basic super-polymer composition and processes for producing it. They systematically investigated the whole array of molecular variations with properties potentially similar to nylon, blanketing their findings with hundreds of patent applications to prevent other firms from developing an effective substitute. [26]

Smaller enterprises obviously lack the facilities and capital to follow DuPont's example. However, not every patentable innovation is susceptible to infringement. Furthermore, until the patent is actually issued, the invention and the process by which it is made can remain secrets, giving the patent holder a substantial head start in producing and 
marketing. Many patent applicants delay actual issuance of a patent for as long as possible, seeking to prolong the "patent pending" period, during which time the product is protected from infringement, while its details remain secret.

The objection that most patents issued by the patent office are probably invalid, judging by the high proportion held invalid in the appellate courts, raises a complicated question. Patent litigation is extremely expensive. Large companies with vast economic resources and sizeable patent departments are at a considerable advantage over small firms and individual inventors who simply cannot afford much litigation. Thus, if a private individual who invented and patented a new kind of concentrating collector found that the patent was being infringed by a multinational corporation, the patent might be practically worthless because the inventor could not afford to sue. Licensing might provide a compromise solution in such situations.

On the other hand, the frequently circulated statements as to the percentage of patents that are invalid, are probably somewhat misleading. It is true that since 1930 , courts have shown increased hostility to patent validity. One study [27] found that in 1929 and 1930 , approximately $45 \%$ of patents adjudicated in reported decisions were held invalid; $62 \%$ were found invalid in $1933 ; 68 \%$ in 1940 ; and $71 \%$ in 1945 . More than one-half of the patents that are litigated to the Courts of Appeal are found to be invalid. However, Judge Howard T. Markey, Chief Justice of the United States Court of Customs and Patent Appeals, has contested the interpretations placed upon these figures:

The number of patents adjudicated by the appellate courts between 1968 and 1972 , for example, was less than $1 / 3$ of those adjudicated in the district courts, only $11 \%$ of those on which suits were filed, and less than $2 / 10$ of $1 \%$ of those issued. Between 1953 and 1971 , over $1,000,000$ patents were issued. Only 1,080 were litigated, or $0.1 \%$. [28]

He also points out that $50 \%$ of patent-valid decisions are not reported, while only $8 \%$ of patent-invalid decisions go unreported. Judge Markey concludes:

Hence the myth that U.S. courts are hostile to patents, the myth that court decisions reflect low standards of patentability in the Patent and Trademark Office, and the myth that most issued patents are either invalid or likely to be declared invalid by a hostile court are all smoke and fog, $r$ ising from a moor of statistical quicksand. [29]

In the solar industry of today, bursting with invention and innovation, a firm's patent position may be a crucial element in its chances for success. There are several reasons why patents might be particularly important to smaller businesses. The benefit offered by a patent is, of course, the right to exclude competition. Large corporations-with funds for advertising, ability to cut costs through mass production, established distribution networks, and recognized names-have less to fear from competition than smaller enterprises, which can find themselves driven from the market as their own inventions are sold more cheaply and successfully by others. Patents offer the possibility of keeping other companies from producing or selling the product, and/or the possibility of licensing other companies to manufacture and sell, in return for royalties to the patent owner. Licensee companies will of ten pay a larger royalty on a license for a patented invention than for unpatented know-how or trade secrets. In addition, an inventor or company that fails to apply for a patent may find another enterprise successfully patenting the invention. The result would be that those responsible for inventing the particular commodity or process could be deprived of the ability to exploit it. 


\subsection{TRADEMARKS}

Trademarks constitute an alternative means for protecting solar knowledge, although they differ from patents in that patents relate to the technology itself, while trademarks and trade names are linked with the marketing of goods and services. The term "trademark" can apply to any "sign, device, or mark by which the articles produced or dealt in by a particular person or organization are distinguished or distinguishable from those produced or dealt in by others" [30]. Justice Holmes described a trademark as a "distinguishable token devised or picked out with the intent to appropriate it to a particular class of goods and with the hope that it will come to symbolize goodwill" [31]. A trademark right arises from use in connection with a particular product, and exists at common law apart from any statutes [32]. As a result, trademark protection may exist simultaneously on three levels: common law, state statutory, and federal statutory.

Early federal attempts at regulation of trademarks were purportedly enacted under the same constitutional authority as patents and copyrights-the power to promote the "Progress of Science and Useful Arts" by giving exclusive rights of limited durations to "Authors and Inventors" [33]. These early trademark laws were judicially overturned as exceeding the scope of the authority granted by the Constitution [34]. Later legislation contains language [35] that the enactments are pursuant to the power of Congress to regulate commerce between the states [36]; these statutes have been upheld as Constitutional.

The general purpose of trademark regulation is to protect businesses from unfair competition in the form of copying or imitating signs, symbols, etc., which would otherwise identify the source or origin of a particular product [37].

A trademark right arises from use and has no existence apart from the particular product or business with which it is used [38]. Federal and state legislation provide for registration of trademarks that have been brought into existence through use. Such registration is not necessary to create the trademark and does not, apart from actual use, create any rights [39]. Registration does have several advantages, however. It provides constructive notice to other potential users of the same sign or symbol that the particular trademark has already been taken [40], and it will be considered as prima facie evidence (evidence which the opposing party must actively disprove) in a court contest as to the validity of a trademark [41].

The right to exclusive use of a trademark is generally based on priority of appropriation; in other words, the first party to use a particular sign, symbol, etc., within a given competitive territory gains the exclusive trademark right [42]. Where two persons or companies are independently using the same trademark in separate marketing territories, wholly remote from each other, a concurrent right to the trademark may arise [43]. Otherwise, the owner of a trademark has injunctive relief, accounting of profits, and damages available to prevent infringement [44]. The United States Supreme Court has held that state unfair competition laws which forbid copying by one manufacturer of another's unpatented product are unconstitutional [45], although states may require manufacturers to identify articles resembling another company's product, as their own [46]. These rulings increase the importance of trademarks; if solar competitors may freely copy each other's unpatented products, protection by trademark is essential for capitalizing on a company's goodwill connected to a particular product. 
Unlike patents and copyrights, trademarks are of potentially infinite duration, although they may be abandoned through nonuse [47]. They may be assigned or licensed, but only in connection with the actual product with which the trademark is associated [48].

In the solar industry, trademark protection may be of particular importance in the marketing of systems for heating and cooling buildings. Devices such as flat-plate collectors may not always be patentable or worth patenting, and the difference between collectors may not be physically obvious to consumers. At the same time, competition is intense, with hundreds of companies producing collectors [49]. Trademark rights can protect the investments of companies in developing and marketing such collectors, or any other solar technology with a broad consumer market, such as woodburning stoves. They can also promote consumer confidence in reliable solar manufacturers and distributors.

\subsection{TRADE GECRETS AND KNOW-HOW}

Much solar information that is of commercial or industrial value is not protected by the patent system. Sometimes an invention or process offers a significant benefit to users, but fails to meet the requirements for patentability. For example, a modification in solar collector design might produce increased efficiency, but the advance over prior knowledge or art might be too insignificant to meet the criteria for invention, under the patent statute [50]. Also, there is knowledge that is based on accumulated experience, but that does not constitute a tangible product to which patentability criteria can be applied. An inventor might know, for example, how best to care for a particular machine or the conditions under which a particular chemical process will produce optimal results. This knowledge, though unpatentable, might consist of a thousand petty details and often constitutes a large portion of the value of the invention itself.

Besides unpatentable information, there are situations where a new device or process might be patentable, but the inventor, or the company that controls the invention, might not seek a patent [51]. The law does provide protection for such unpatented information; however, this protection differs significantly from the rights created under the patent system.

The terms "trade secret" and "know-how" are of ten used interchangeably. Distinguishing between them is made difficult by the fact that the authorities themselves are in disagreement as to the exact meaning to be given to each term [52]. The most commonly cited definition of trade secret is found in the Restatement of Torts.

A trade secret may consist of any formula, pattern, device or compilation of information which is used in one's business, and which gives him an opportunity to obtain an advantage over competitors who do not know or use it. It may be a formula for a chemical compound, a process of manufacturing, treating or preserving materials, a pattern for a machine or other device, or a list of customers... it is not simply information as to single or ephemeral events in the conduct of a business, as, for example, the amount or other terms of a secret bid for a contract or the salary of certain employees.... A trade secret is a process or device for continuous use in the operation of the business.

The subject matter of a trade secret must be secret. Matters of public knowledge or of general knowledge in an industry cannot be appropriated by one as his trade secret. [53] 
Certain types of information, such as engineering or management expertise, may be commercially valuable but not sufficiently secret or confidential to qualify for trade secret status. Some authorities have found it necessary to define know-how as covering a broader range of technology-related information than the term "trade secret" covers [54].

Legal protection for know-how is neither federal, nor statutory. It has evolved at the state level on a case-by-case basis. Trade secret protection of a potentially unlimited duration, as long as it remains secret, may be protected. Whereas patents are enforceable against everyone, trade secret law offers no protection against others who discover the same process, method, etc., by legitimate means [55].

The law will impose a duty to refrain from using or disclosing know-how in three categories of circumstances: (1) contractual agreement, (2) confidential relationship or constructive trust, and (3) outright fraud or theft. If a party obtaining protected information has made certain agreements in exchange for the information, the courts will ordinarily enforce the agreement [56]. If the relationship between a party with information and the party from whom it was obtained was one of special confidence or trust (as where an employee learns of an employer's trade secrets), the law will prevent abuse of that confidence or trust [57]. If information is obtained through clearly unlawful or inappropriate means, the law will punish the wrongdoer [58].

The categories overlap in many ways. Judicial enforcement of a contract, particularly when the terms are ambiguous, may be affected by the extent to which relations between the parties were confidential [59]. Before a contract is formed in a licensing situation, there is a period of negotiation during which some trade secrets may be revealed. If there had been no express agree ment concerning such disclosures, the courts must decide if a confidential relationship existed [60].

Theft of trade secrets is regulated by statute and punishable as a criminal offense [61]. Otherwise, the person to whom the trade secret was disclosed may be enjoined from using it or from divulging it to others; he or she may be held accountable for any damages suffered by the trade secret owner should it be made public; and any profits earned by an improper expropriator of a trade secret may be returned to the owner. However, if a secret is disclosed to an innocent third party who is not aware of any impropriety, remedies are unavailable against such third party [62]: The property rights of the trade secret owner terminate at the point of disclosure to any such innocent parties.

Trade secret protection is available for solar knowledge that does not meet patentability criteria [63]. Information that constitutes a trade secret [64] does not have to be absolute; it may be known to a few others-but it must not be common knowledge in the industry [65]. As a second prerequisite to trade secret protection, the information must be in use [66]. Third, some advance over prior art-obviously not as much as for a patent-is of ten required by courts [67]. Information that does not meet these criteria will not be protected by finding a confidential relationship, and even express contract provisions forbidding disclosure (including royalty provisions in a license agreement) have been held unenforceable by courts when the trade secret requirements are not met [68].

Trade secrets have several disadvantages as compared to patents. Trade secrets rarely remain secret for long. As a result, the protection soon disappears. Patents, by contrast, are protected for 17 years under all circumstances. (A patent offers the right to 
exclude all others from utilizing the invention without permission, regardless of such 'others' independently acquired knowledge, and a patent will often bring higher royalties than a similar trade secret in a license agreement.) The damages that can be collected by a patent holder are, under some circumstances, greater than those collectible by a trade secret owner [69].

However, there are instances when a patentable invention might be better protected under trade secret law than under a patent. One author has compiled a list of 11 such situations:

(1) If the company lacks the financial resources to enforce its patent in an area where the competitors are the giants of American industry and who might decide to infringe upon discovering the invention in the issued patent.

(2) If the innovation is a computer program, process, or machine to be internally used in a plant or if it is for converting raw materials or components into salable goods which do not possess features identifying the innovation as their source of manufacture, thereby making the detection of infringers extremely difficult, if not impossible.

(3) If the innovation can only be given limited patent protection which can be designed around without too much difficulty by competitors who will have the same competitive benefits stemming from the modified innovation that incorporates the basic inventive concept as that being received finm the patented innovation.

(4) If the innovation life cycle is not expected to be more than five years, due to rapid obsolescence or a limited market, thereby making a patent no more advantageous than trade secret protection.

(5) If the patent would quickly make the owner of a dominating patent aware of the infringing use or sale which otherwise might go unnoticed as a trade secret.

(6) If the patent prosecution indicates that only narrow claims, having nominal protective value, are allowable-in which case abandonment of the patent application will preserve trade secret protection thereby excluding competition for a period longer than that which would result upon patent issuance.

(7) If the owner wants to avoid the high risk of patent invalidity and the immediate publicity and industry-wide knowledge thereof, in contrast to losing a case against an alleged expropriator of one's trade secret without loss of the trade secret protection as against others.

(8) If the product or service utilizing the trade secret has an indefinite commercial life substantially greater than 20 years, by which time a patent would expire, and it is strongly felt that the secret will not be cracked, discovered, or wrongfully expropriated. 
(9) If the company is judicially or contractually required to license its patents in a certain area to competitors.

(10) If the company wants to avoid the risk of compulsory patent licensing abroad and other patent penalties, due to antitrust violations.

(11) If the company wants to avoid compulsory licensing required by statute, such as Section 308 of the Clear Air Act of 1970, regarding patented air pollution control inventions and proposed laws Congress is presently considering with respect to all patentable inventions affecting the public health, safety, and welfare. [70]

While several of the enumerated situations may raise legal and ethical questions, e.g., No.'s 5, 9, and 11 , the list is helpful in indicating considerations that may influence the kind of legal protection sought for a particular invention. Trade secrets are an increasingly attractive for $m$ of legal protection for other reasons as well. In 1969 , the United States Supreme Court ruled that a licensee could raise patent invalidity as a defense to a suit for payment of royalties under the license [71]. This ruling, coupled with the perceived [72] hostility of courts towards patents, raises serious questions as to the stability of licensing agreements. By contrast, courts have been relatively receptive to trade secret protection in recent years [73]. Thus, if any doubt exists as to the patentability of an invention from which the inventor hopes to profit by licensing, it may be wiser to retain trade secret status for the invention, rather than seeking a patent.

In relation to the solar industry, discussion of specific trade secrets would be largely speculative at this stage. However, one possible example of such a secret is in the area of photovoltaics. A major.problem facing that technology is the expense of producing silicon cells. Much of this expense is labor cost. If a particular firm were to develop labor-saving techniques not so or iginal as to be clearly patentable, but capable of satisfying trade secret criteria [74], the firm would wish to keep such information secret. They could exploit it on their own, and/or license others in exchange for royalties and a nondisclosure agreement.

\subsection{COPYRIGHT LAW}

Copyright law "protects the writings of an author against copying" [75]. The kinds of works protected include literary, musical, artistic, and dramatic productions, as well as motion pictures and sound recordings [76]. Federal copyright law, like patent law, is authorized by the U.S. Constitution, Article I, Section 8, Clause 8. Unlike other protection for intellectual property, copyright law is not concerned with ideas, only with tangible forms of expression [77].

Fcdcral copyright law was thornughly revamped, for the first time since 1909, in the Copyright Revision Act of 1976 [78]. The purpose of this act was to modernize copyright law in keeping with technological advances [79]. Many of the implications of this modernization are still unclear, as there have not yet been enough cases calling for judicial interpretation of its provisions.

Prior to 1976; unpublished materials were protected by common-law copyright, also known as right of first publication [80]. The 1976 law expressly preempted all common law and state statutory rights in any subject matter covered by its provisions [81], and at 
the same time, extended federal copyright protection to unpublished material [82]. The rights conferred by statute, on all protected works, published or otherwise, are exclusive and include the right to copy, translate, publish, display, and perform the work [83]. A copyright in any work created after January l, 1978 endures for the author's life and 50 years after the author's death [84]. Other provisions of the new statute treat copyrights obtained before the act came into effect [85], anonymous authors [86], and works made for hire [87].

Federal copyright requirements include notice, deposit, and registration. Notice is required on any work published in this country or elsewhere, in order to obtain copyright protection [88]. Omission of notice does not invalidate the copyright if reasonable efforts are made to correct the omission within five years [89]. The owner of a book copyrighted in the United States is also required to deposit two copies with the Copyright Office in the Library of Congress. While this requirement does not affect the existence of a copyright, failure to comply carries specific penulties [90]. The Register of Copyright may waive the deposit requirement in certain cases [91]. Registration with the Copyright Office is provided by statute for both published and unpublished materials [92], but registration is neither mandatory nor a prerequisite for obtaining a valid copyright [93]. However, no suit for copyright infringement may be brought unless registration has been sought [94].

Remedies for infringement include: injunctions [95], impoundment of infringing articles [96], actual damages [97], and, alternatively, statutory damages of as much as $\$ 50,000$ for willful infringement [98]. The act also allows eriminal penalties under certain circumstances [99].

The role of copyright in relation to proprietary rights in solar technology is limited, but worth discussing briefly. Copyright protection can be used as a supplement to trade secret rights. However, if obtaining the ideas involves copying a form (e.g., mechanical drawings, or a written description of a complicated process), and if such form has not yet recelved general publication, copyright law provides a supplemental set of remedies [lơ], such as statutory damages. In addition, a copyright provides guaranteed access to the federal courts. 


\section{SECTION 3.0}

\section{LICENSING OF INDUSTRIAL PROPERTY}

The preceding discussion has focused almost exclusively on protecting intellectual property from infringement by others. This, of course, tells only part of the story. As one writer puts it in relation to patents:

Having a patent, however, is merely having a piece of paper which states that the inventor is entitled to protection for his property rights. It puts no money in the bank, it creates no marketable product and it does not itself prevent others from infringing upon the patentee's rights. Obtaining the patent provides the basis, however, for exploitation of those property rights. [101]

One approach to exploiting a patent, or unpatented information, is to attempt to raise enough capital to manufacture and sell one's own product. In the solar energy field, this approach is hampered by a variety of obstacles, including the difficulty of raising the necessary capital, and frequently, the lack of business experience on the part of the inventor turned entrepreneur. Licensing provides another approach.

Licensing involves an agreement by one who has invented and patented a new device, with another that can produce and/or sell the device in exchange for specified royalties for units. The simplicity ends with this description, however, for licensing generally involves complex transactions raising a variety of legal and practical questions. This paper will provide an overview of the basic laws governing licensing transactions, a few practical issues which arise in licensing transactions, and some of the advantages and disadvantages of using licensing arrangements.

But this paper cannot replace the advice of experienced legal counsel. Given the complexity of licensing transactions, a do-it-yourself manual is not realistic and might cause more damage than good.

\subsection{LEGAL ASPECTS}

All forms of intellectual property-patents, trademarks, trade secrets, and copyrights within the solar energy field may be licensed. The term "industrial property" is frequently used to denote patent, trademark, and trade secret rights, but not copyrights; which are excluded because they are related only peripherally to industry [102]. The scope of this paper is narrowed even further to include only patents and trade secrets or know-how, because those two categories are the most directly involved in the development of solar technology.

Federal patent laws provide that a patent may be legally assigned in a written instrument [103]. "Assignment" describes a transfer of rights, usually including the whole interest in the thing assigned [104]. In 1891, the United States Supreme Court held, in Waterman v. Mackenzie [105], that an assignment of a patent only takes place if the rights transferred include either (1) the whole patent, including the exclusive right to make, use, and sell the invention throughout the United States; (2) an undivided share of that exclusive right; or (3) an exclusive right under the patent throughout a particular geographical area within the United States [106]. A transfer which meets any of these three criteria (i.e., 
an assignment) is said to "vest" in the assignee, "title" to the patent interest, which includes a right to sue others for infringing the patent [107].

By contrast, a "license" is a transfer of interest in a patent that does not meet the criteria for an assignment [108]. The three rights which comprise a patent-the right to use, the right to make, and the right to sell-may be granted separately [109]. Where less than all three rights are given, as when an agreement includes the right to use but not the rights to manufacture and sell, there is no assignment. A license, unlike an assignment, does not ordinarily include the right to sue infringers [110].

Know-how may also be assigned, and again, a transfer of rights that falls short of an assignment is a license. Unlike patents, which last for only 17 years, know-how may last forever if no one else discovers the secret. Thus, assignments of trade secrets must be for the lifetime of the secret information. Until recently, there was some doubt in the federal courts as to the enforceability of trade secret license agreements, on the grounds that state trade secret protection was preempted by federal patent law. In 1974, the Supreme Court eliminated such doubts, holding that the constitutional grant of congressional authority to give patents does not preclude state regulation of unpatented inf ormation [111].

Whether a particular agreement would be considered a license or an assignment will depend on individual facts and circumstances of the agreement. The terms used by the parties to describe the arrangement are relevant but not controlling of a court's decision [112].

A license may be granted on an exclusive basis whereby the licensor agrees not to license anyone else [113], at least within a particular territory, and also (unless otherwise agreed) not to exploit the patent or trade secret [114]. An exclusive licensee may initiate infringement litigation in the licensor's name, without the licensor's permission, although a court may decide that the licensor is indispensable to the suit, and must be joined for the litigation to proceed [115]. A nonexclusive license is essentially an agreement by the licensor not to sue the licensee for infringing the patent or exploiting the protected know-how. Sometimes the parties even call the agreement a "covenant not to sue," rather than a license, perhaps to avoid the possibility of any greater, "implied" licenses being read into the agreement [116]. A distinction, similar to the difference between an assignment and a license, controls the characterization of income to the licensor for tax purposes. When the agreement confers "all substantial rights" in the patent or trade secret, the income it generates qualifies for favorable capital gains treatment; where any substantial rights are withheld by the licensor, then the licensing royalties are taxed as ordinary income [117].

As we have seen earlier, patents (including assignments of patents) are regulated by Federal statute, while know-how is protected by state law. However, a license is a contract, and contract law principles are (with certain notable exceptions) creatures of the common law: products of decisions by judges of the state appellate courts. As a result, any generalizations about the contract law aspects of licensing arrangements are subject to variation from state to state.

A license, like most contracts, may be in writing, or in some cases, created orally [118]. A series of informal written communications may create a license, so long as all of the essential terms are included in such writings [119]. Under the "parole evidence rule," oral evidence may not be introduced to change the terms of a contract which has been fully reduced to writing [120], unless the evidence merely explains ambiguity in the 
writing [121], or pertains to agreements made subsequent to creation of the original contract [122]. Oral license agreements may conflict with the "Statute of Frauds," of which each state has its own version [123]. The Statute of Frauds generally requires certain kinds of contracts to be in writing in order to be enforceable. For example, an agreement which is not to be performed within one year of its making, falls within the statute and must be in writing to be valid [124]. However, partial performance of a contract's terms may remove the agreement from the requirements of the statute and ensure its enforceability [125].

It is generally advisable to make solar licensing agreements in writing. A written agreement has the following advantages: avoiding Statute of Frauds difficulties; discouraging either of the parties from seeking to deny, or otherwise renege upon, the contract as a whole; and reducing the possibility of uncertainty and/or litigation over specific contract provisions. Licensing agreements are complex arrangements, and it is best to spell out every detail, particularly when know-how is involved.

Licenses, like other contracts, may be express or implied. An express license, oral or written, is created by consent of the parties, but may be held invalid if contrary to law or public policy [126]. An implied license arises by operation of law, from the conduct of the parties, and will never be held invalid [127]. As expressed by the United States Supreme Court in DeForest Radio Telelphone \& Telegraph Co. v. United States [128]:

No formal granting of a license is necessary in order to give it effect. Any language used by the owner of the patent or any conduct on his part exhibited to another from which that other party may properly infer that the owner consents to his use of the patent in making or using it or selling it, upon which the other acts, constitutes a license and a defense to an action for a tort. [129]

Underlying the creation of licenses by implication is the legal doctrine known as estoppel:

any conduct by which the owner of the patent induces the person who employs the invention to place himself in a situation where he must suffer injury, unless his right to practice the invention is conceded, will be regarded as implying such a right and as estopping the owner of the patent from asserting his prohibitory powers in its defeat. [130]

In other words, where the actions or words of one party are such that it would be unjust to deny a license to the other party, the license will be implied. Obviously, whether or not a license will be implied, and what terms will be implied, depend upon the circumstances.

Thus, the sale by. (or authorized by) a patent holder of articles which can be used in the patented process may not itself imply a license [131]; but such sale of an article which can only be used in the patented process implies a license under the patent [132]. Where the owner of several patents gives an express license of rights in one patent, and exercise of those rights would necessarily infringe upon a second patent held by the licensor, a license under the second patent will be implied [133]. Implied licenses grafted onto express licenses are limited to rights necessary to make the contract effective [134].

Implied licenses may also arise in connection with contracts for the sale of solar knowhow. Some licensing arrangements involve disclosure of the subject matter of soon-tobe-acquired patents, or of trade secrets not explicitly made part of the original agree- 
ment. However, the contract may be written in such a way that precludes finding implied licenses [135]. The key in providing such protection is to list explicitly all elements of know-how included and excluded from the license.

Confusion in the area of implied licenses is likely to arise when the parties are inexperienced in licensing agreements, and/or rely on informal or unstated mutual understandings. Much of the solar energy industry consists of private inventors and small enterprises. Many of the individuals involved may not wish to enter complicated, formal arrangements, or to hire expensive legal assistance in working out the details of such arrangements. However, the consequences of too little care in drafting can be far more vexing than the discomfort of too much formality, and the cost of a skilled attorney to help draw up the contract is far less than the price of litigation.

Certain contractual provisions are peculiar to licensing arrangements. A licensor may $w$ ish to ensure access to any improvements to the licensor's invention that may he mare by a licensee. By a "grant back" clause, the licensee grants back to the licensor rights to any improvements it might make on the article, process, etc. Similarly, a licensee may wlsh to insert a clause ensuring access for itself to the results of future research and development efforts by the licensor. It should be noted that grant back provisions calling for exclusive licenses or assignments to an original licensor of patents to be obtained may violate the antitrust laws [136], although nonexclusive licenses back pose no such problem [137].

If two parties each have patents or other industrial property rights which the other could use, they may choose a cross-licensing arrangement as an alternative to separate licensing transactions with royalty provisions flowing both ways. The most common situation for cross-licensing is where one party owns a patent which dominates or "blocks" the other party's invention [138]. If the effect of the cross-licensing scheme is to restrict the flow of licenses to a certain group, and thereby to restrict competition, an antitrust violation may be found [139]. If the free interchange of licenses is unimpeded, cross-licensing will generally be upheld in the courts [140].

Licensors frequently seek to restrict the nature and extent of the rights conveyed in the license agreement. For a patent holder or the owner of a trade secret, such restrictions may seem to be the logical extension of the monopoly already possessed. After all, a patentee is free to sell as many or few of his inventions as he or she wishes, to whomever he or she wishes, at whatever price the market will allow. However, when such patentee or trade secret owner seeks to impose limitations on a licensee, the provisions and/or the entire contract may be invalid under the antitrust laws or the so-called patent misuse doctrine. The patent misuse doctrine forbids a patent holder to use a patent to extend monopolistic control over commerce in items not covered by such patent [141]. There are, however, at least five types of restrictions imposed by licensors which are commonly upheld: (1) duration, (2) manufacture, use, or sale, (3) field of use, (4) geography, and (5) quantity.

Durational limitations are upheld as long as they are within the unexpired term of the patent. A patentee may limit the license to a shorter time than the full 17 years of the patent, or whatever is left of the 17 years at the time of the licensing agreement. But, collecting royalties for use of the invention beyond the expiration of the underlying patent has been declared a patent misuse by the Supreme Court [142]. A trade secret license, by contrast, may be of any duration. It is currently unclear whether a royalty provision may be enforced after the secret information has become common knowledge [143]. However the courts ultimately resolve this question, parties to a know-how license are well advised to make explicit contractual provision as to terms of the agreement and 
as to the consequence of any future public disclosure of the information. Such provision might be made explicitly severable from the balance of the contract in the event future decisions hold royalties from know-how licenses invalid after public disclosure of the trade secrets involved.

The right to divide a patent into three separate rights-rights to make, to use, and to sell-was established over 100 years ago [144]. A more controversial, but generally permissible, way of splitting patent rights limits the field or industry in which each licensee may use the invention- "field of use" restrictions. Thus, separating rights relating to vacuum tubes into home broadcasting vs. commercial uses was upheld by the Supreme Court in General Talking Pictures Corp. v. Western Electric Co. [145] .

Grants of exclusive rights within particular territories are expressly sanctioned by the federal patent laws [146]. A patentee is apparently permitted to restrict the quantity of items which may be produced by a licensee on the theory that a patentee is not ordinarily obligated to work his invention at any time, and some others may not work the invention without the patentee's consent [147]. However, such arrangements might eventually be successfully challenged as restraints upon competition and violations of antitrust laws [148]. It has often been said that the public interest is an invisible third party to all licensing transactions.

Congress has stated explicitly and repeatedly that the development of alternative, renewable energy forms is a national policy objective. It is very possible that restrictions in licensing agreements which might be generally valid, could be challenged successfully when included in agreements regarding solar energy technology, if they have the effect of limiting public access to solar technology. Where technology protected by a patent was needed by the public, a patentee has been refused an injunction against an outright infringer [149]. By similar logic, a court is unlikely to uphold any contractual limitation which keeps important technology off the market.

In the absence of explicit warranty language, a licensing agreement does not warrant by implications that the patent or trade secret is commercially marketable [150], or that the licensee's use of the invention, product, etc., does not infringe upon another's dominating patent. This may be significant in the solar energy field, where many different people may be working on similar ideas, and the economist feasibility of marketing solar products remains a major problem. Where an express warranty against third-party infringement actions is included, it usually takes the for $m$ of an indemnity or "hold harmless" clause, whereby the licensor agrees tó pay any licensee liability deter mined in infringement suits [151].

Because a licensing agreement does not necessarily imply a licensor obligation to sue third parties for infringement of the licensed patent [152], the license agreement should explicitly allocate the obligation to sue and the burden of paying for any lawsuit.

A licensee obligation to use best efforts to exploit the licensed subject matter has been implied in exclusive, but not nonexclusive, licenses [153]. Most license agreements include a "best efforts" clause as a matter of course. Where the license includes such an express covenant, the licensor may sue to rescind the agreement or to collect damages, if the licensee fails to perform.

Another provision commonly found in licensing agreements is a covenant by the licensee to mark all products in accordance with patent law requirements [154]. This provision is 
to protect the licensor, who will usually be unable to recover damages for infringement by $a$ third party if the patented product was sold without proper marking [155] .

Traditionally, a patent license does not imply a warranty that the patent is valid. Recent Supreme Court decisions have altered this principle. Under the traditional view, a licensee was not permitted to contest the validity of the patent which was the subject matter of the license, under a doctrine known as "licensee estoppel" [156]. In the 1969 decision in Lear, Inc. v. Adkins [157], however, the Supreme Court reasoned that puhlip interost reyulres that all ideas not deserving patent protection be placed in the public domain and that "licensees may of ten be the only individuals with enough economic incentive to challenge the patentability of an inventor's discovery" [158]. The court concluded that a licensee ought to be permitted to raise patent invalidity as a defense to a suit for royalty payments [159]. Therefore, a licensee may now withhold myalties from the time ite patent validity suit commences. The original rule that a licensor does not implicitly warlanil pulent valldity is still alive to the extent that the licensee may not recovcr royalties paid prior to the bringing of such a suit [160]. Two years after Lear, BlonderTongue Laboratories, Inc. v. University of mlinois Foundation [161] abrogated the "mutuality" rule, which had traditionally prevented a licensee from asserting a prior judgment of patent invalidity as a defense to a suit for royalty payments unless the licensee had been a party to, or otherwise bound by, the earlier suit. A side effect of these decisions has been to increase the popularity of trade secret, as opposed to patent protection for intellectual property.

\subsection{ADVANTAGES AND DISADVANTAGES OF LICENSING}

From the standpoint of the licensor, a party who already controls potentially valuable intellectual property rights in solar energy, the following benefits might be experted from a licensing arrangement:

- Royalty income. Where the choice is between licensing and not using the information, any royalty is greater than no income at all.

- Lower capital requirements. The cost of reducing an invention to practice and patenting it is only a small fraction of the entire cost involved in manufacturing and marketing a finished product. A private solar inventor or small patentee company may be unable to obtain enough capital to cxploit the intellectual property it owns. Within large corporations, existing capital is of ten subject to heavy intracompany competition. Management may be unwilling to undertake the high degree of risk involved in sponsoring a new product, which has been a persistent obstacle to the commerclalization of solar energy.

- Less involvement in marketing and production. A private inventor or a small company may lack the desire and/or the business experience to produce and sell large quantities of goods. Similarly, a larger company may have created an invention as a spin-off from other research efforts, but manufacturing and marketing the invention may be wholly outside the firm's existing productive capacity and marketing apparatus. Either way, it could be advantageous to license-out to an enterprise with existing skill and capacity in appropriate areas.

- Expanding the market. Even when the licensor is already marketing the 
goods, the licensee's additional efforts to advertise and otherwise promote the product may increase market acceptance of solar products. In some cases, prospective purchasers will balk unless more than one source of supply for the goods can be assured.

- Meeting the demand for the product. If the number of customers for the product has increased rapidly so that the licensor is unable to supply all their needs, licensing may be necessary to meet all commitments.

- Competitive Edge. Although the license may enable the licensee to produce goods which compete against the licensor's own products, this competitive effect is offset by the licensor's ability to impose costs on the licensee through setting royalty rates.

- Access to additional research and know-how. The licensee may improve the product or have information in related areas. Mutually beneficial technological advances in flow of information can be-assured through appropriate grant-back and cross-licensing provisions in the agreement. This would help promote the efficiency of solar devices.

- Favorable publicity; improved recognition. Licensing-out of ideas (which might otherwise languish) may enhance a company's image to prospective investors, employees, and associates in joint endeavors.

- Establishment of relations with other companies. A licensing arrangement may provide the basis for other mutually profitable exchanges and business agreements between the present licensors and licensees.

- Forestalling infringement by others. If a patent is sufficiently valuable and/or legally weak, infringement by other companies is likely. Infringement litigation is very expensive; for a small company, it may be impossible to afford a suit against a large corporation which infringes the smaller concern's patent rights. Where a license is made available on reasonable terms to a potential infringer, infringement may be avoided entirely.

- Discouraging industrial espionage or parallel research. When a license is available, other companies are less likely to resort to illicit means of obtaining a trade secret or to spend large sums on research in order to duplica te a secret process or to "invent around" a patent.

- Expand income from a "process." Where the patent or trade secret relates not to a final product, but rather to a process used in the licensor's business or factory, etc., the economic benefits deriving from internal use of the process may be augmented by licensing-out to other companies, which can use the process in their own operations.

- Special advantages relating to foreign markets. A variety of factors, ranging from geography to international politics, might make licensing the best, or even the only way, in which to conduct business in a particular country. [162] 
A potential licensor must balance these advantages of licensing against the following disadvantages:

- Royalties are only a portion of the total profit from exploitation of the patent. Where a patentee is in a position to efficiently manufacture and sell the protected product itself, and therefore to reap all the profits for itself, the total financial rewards may be much greater than mere royalty income.

- Surrender of monopoly rights. In divulging information or granting rights under a patent, a licensor may be creating or aiding its own competitors. Furthermore, where an exclusive license is granted, the licensor may be forfeiting its own rights to operate in the area covered by the agreement.

- Licensing agreements have hidden costs. Such costs may include: legal and consulting fees; expenses of searching for, and negotiating with, prospective licensees; costs of ongoing supervision of the licensee's performance of the contract; costs of technical assistance connected with use of the subject matter of the agreement by the licensee; and expenses of joint promotion of the product.

- Legal entanglement. Because of the complex subject matter of licensing contracts, disputes over the meaning of provisions are not uncommon. Antitrust suits are always possible: paradoxically, a patent owner who retains monopolistic control is less susceptible to antitrust attack than one who licenses-out the patent rights subject to restrictions [163]. A third potential source of litigation may be the greatest deterrent to licensing: the danger, since Lear v. Adkins [164], that the licensee will seek to escape paying royalties by attacking the validity of an underlying patent.

- Licensee's access to licensor's know-how and new products. The close technical ties between the licensor and licensee may result in disclosure to the licensee of valuable information which the licensor did not wish to include in the license, and for which the licensor will be unable to collect royalties or other payments.

From the licensee's perspective, another set of possible advantages and disadvantages emerges. Some of the potential licensee benefits include:

- Access to technology. If a secret process will significantly reduce costs within the licensee's enterprise, or if a patented product has a ready demand which the licensee wishes to meet, a license will produce an economic benefit equal to the difference, if any, between the royalty rate anticipated and extra profits generated by such technology.

- Lower expenditures on research and development. If a product, or process, already exists, obtaining a license may be faster and more economical than discovering it-whether from scratch or through reverse engineering -or than inventing around a patent. 
- Expanded product line. Simply, a license may make available new products for a company to offer, thereby broadening its economic base.

- Competitive strength. If rapid technological strides are being made within an industry, all who wish to remain competitive in that industry must keep up with that pace.

- Access to know-how and improvements. Just as the licensor may bind the licensee to provide access to future improvements on the process or product, so the licensee may obtain contractual assurance that the benefits of the licensor's future technical progress will be available to the licensee. Also, many licensing arrangements provide extensive technical support, making the skill and experience of the licensor available to the licensee.

- Removal of barriers of dominating or "blocking" patents. A licensee's own innovation may be unusable without rights under another patent, which will have to be obtained through licensing.

From the licensee's perspective, some of the potential disadvantages of licensing include:

- The cost of the license. The expected economic benefits from the license may not justify the expense of paying royalties plus related costs.

- The licensor's competitive advantage. If the licensor is also marketing the product, the licensee must attempt to compete from a cost basis which is increased by royalty payments. The licensee's relative inexperience with this product may also be a competitive disadvantage.

- The untested nature of the information. Usually, the marketability of the subject matter of the license has not yet been established. Often, even its technical quality is still uncertain.

- The cost of further research and development. Turning an invention into a marketable product is frequently many times more expensive than the initial cost of inventing it [165]. Also, the licensee may need to expend significant resources to adapt its existing facilities to the new product, and vice versa.

- The need to strengthen the licensee's own research and development. The $R \& D$ efforts which are avoided by licensing may be desirable activities. Research might turn up a better solution to the problem or valuable related discoveries. A solid, in-house research program, although expensive, has long-term benefits which may outweigh its costs.

- The weakness of the underlying patent. The prospective licensee may question the patent's validity or the limited scope of its protection. In such a case, there is a great danger of infringement by other unlicensed enterprises, and therefore, little to deter the potential licensee from infringing instead of paying for a license. 
Ultimately, advisability of a particular licensing agreement, from the standpoint of either party, depends on the facts of the particular situation, including the reliability of the other party, the potential value of the subject matter, and the satisfaction of each party with terms offered by the other.

From the perspective of public policy, the utility for licensing arrangements in the solar industry may involve different factors. Where there exists, as in the case of solar energy, a stated national goal of making technology available to the public, there is a public interest in licensing that may transcend the narrower concerns of private business. It may be in the public interest to promote dissemination of technology by eliminating any barriers to licensing, so long as the government involvement is consistent with basic principles of free enterprise.

Future inquiry should be directed at policy questions, such as the effect of government licensing policies regarding technology produced by government research [166], the effect of antitrust law on restrictive licenses, judicial inroads into patent licensing as in Lear v. Adkins, and the relative merits and dangers of compulsory licensing. 


\section{SECTION 4.0}

\section{BARRIERS TO LICENSING}

It should be clear by now that the chief advantage of licensing is efficiency. In simplistic terms, if $A$ has an invention that is not on the market, B has underutilized production capacity that could be adapted for A's device, and $C$. has a distribution network that is ready to handle new products in the field of A's invention; licensing could enable $A, B$, and $\mathrm{C}$ to efficiently combine their resources and deliver a product to the public. Without licensing, $\mathrm{A}$ is required to manufacture and sell, $\mathrm{B}$ to invent and distribute, and $\mathrm{C}$ to discover and produce-with inefficiency likely to result from each one's lack of experience and/or interest in the added areas of activity, as well as from the duplication of effort.

The efficiency aspect of licensing is underscored by the distribution of costs involved in creating a successful invention:

breakdown of cost, related to effort, indicates that the step we commonly call research and advanced development, including the basic invention, only accounts for about $5-10 \%$ of the total cost ... other activities, which many people don't usually associate with the innovative process, account for about $90-95 \%$ of the total cost. These activities are major pilot plants, engineering and designing the product, tooling and manufacturing including engineering, manufacturing start-up expenses, and market start-up expenses. [167]

Licensing distributes the costs and associated risks among more than one party, and tends to minimize these costs by utilizing existing resources at each stage. This would tend to encourage investment in solar energy technology, which has been expensive and speculative in the nature of its financial returns.

There is reason to believe that licensing is not being used to full advantage and that valuable technology is languishing on research laboratory shelves. The extensive research and development facilities of large corporations are generally believed to be creating far more innovations than the companies are able to exploit at any one time. University laboratories are said to be producing knowledge of enor mous potential, "undiscovered, unrecognized, and unused" [168]. Private inventors may be sitting on important new developments, without access to production or distribution facilities. The following excerpt gives an example of technology underutilization, as well as of the potential role of licensing:

In January 1971 the New York Times published an announcement about a most important U.S. invention, in February the London Times noted the importance of the U.S. invention but clarified the record by stating that British scientists had made the invention 15 years earlier as published in a British patent (the number was cited); in March, Izvestia agreed with the importance of the invention but claimed Russian credit for it based on a publication 25 years earlier in a Russian Journal; and in April, Japan announced the export to the U.S. of the new product, based on the U.S. inverition... the licensee can sometimes get to the marketplace first. [169] 
Hard data is lacking in this area of underutilized technology. Therefore, we cannot know for sure what unpatented information is currently gathering dust in corporate research archives, or even estimate the potential value of patents that have been granted but not exploited.

Reasons why technology may be languishing in laboratories, unexploited and unlicensed, are worth exploring in terms of their possible effect on the diffusion of solar technology. As a recent editorial stated the case:

Hundreds of shoestring scientists and technicians struggle through the land on solar energy systems, underfinanced, understaffed, and short of sophisticated help. Yet the sun shines, the wind blows, the oceans heave, the coal waits, and the concepts are more promising than was the atomic bomb. [170]

A recent study of law and technology in America concluded that "innovations that are adequately financed and intelligently marketed are able to circumvent any inconveniences created by intellectual property law" [171]. This conclusion suggests that the first place to look for technology underutilization is where financing is likely to be inadequate and marketing know-how less sophisticated: the individual inventor and small, struggling, young patentee companies. The importance of the individual in fostering invention should not be underestimated. A widely quoted study by John Jewkes found that, of 61 major Twentieth Century inventions:

More than one-half of the cases can be ranked as individual invention in the sense that much of the pioneering work was carried through by men who were working on their own behalf without the backing of research institutions and usually with limited resources and assistance or, where the inventors were employed in institutions, these institutions were, as in the case of universities, of such a kind that the individuals were autonomous, free to follow their own ideas without hindrance. [172]

Private inventors, small companies, and academic researchers are, as a group, least likely to obtain capital to develop their discoveries. Licensing not only expedites the utilization of technology, but it enables inventors and research laboratories to profit from their discoveries. Besides providing motivation for research, profit provides money for further exploration. At the same time, these underfinanced innovators fare. significant barriers blocking their effective use of licensing.

One barrier is the lack of business or legal experience in many inventors. Licensing is a complex process-finding another party, negotiating the terms, and protecting one's rights during the agreement-which requires sophistication or at least competent advice. The entry-level problem of making contacts with the right parties is illustrative. Consultants specializing in helping prospective licensees and licensors find each other [173], can be expensive, and an individual may have no way of ascertaining in advance how reliable or competent a particular consultant or lawyer is. Licensing within established industries often takes place as a result of informal contacts. Patent lawyers, consultants, executive organizations, distributors, and sales personnel play roles in an amorphous communication network within each industry. Individual inventors and small companies are, by and large, excluded from this network. In some of the various solar energy related industries, there are perhaps thousands of separate participants, ranging from backyard inventors to multinational conglomerates [174]. Existing intra-industry lines of communication are probably not adequate to meet the licensing needs of the many enterprises that constitute the emerging solar energy industry. Though not 
necessarily insurmountable, these difficulties may be sufficiently intimidating as to constitute an effective barrrier to licensing.

Another possible obstacle to full utilization of licensing is the inventors' tendency to overestimate the potential market value of their discoveries, while underestimating the expense involved in further development, production, and marketing. As a result, they are hesitant to share the expected returns under a licensing scheme. A closely related barrier is generalized inventor distrust of the large companies which are likely candidates for licenses.

Perhaps the greatest hurdle discouraging licensing of technology is resistance by large corporations to ideas from the outside. Gaining acceptance from sizable corporations for inventions brought to them by outside inventors is difficult and of ten impossible. The development by Frank Whittle of the jet engine in England [175], of Xerox printing by Chester Carlson, and the Polaroid instant developing camera by Edwin Land in the United States [176] are just a few of the many examples of inventors whose ideas were spurned by the corporate giants until persistence, fueled by scant resources, successfully applied and marketed valuable new technologies.

There are several apparent causes for the lack of corporate interest in private inventors. First, there are instances of a chauvinistic attitude among corporate research and development departments, which operates to exclude outside inventions from serious consideration. This tendency is sometimes referred to as the "not-invented-here" syndrome. Second, the hierarchical structure of many corporations may tend to induce conservatism. Third, corporate officials claim that they have experienced difficulties in dealing with private inventors who lack business sense and may overestimate the value of their own discoveries. Such stereotyping of inventors as irascible individualists may be difficult to eliminate. Probably the most important reason for corporate resistance to outside innovations is the large amounts of time and resources necessary to separate wheat from chaff (useful innovation from impractical schemes masquerading as technology). Jewkes, who fully appreciated the importance of private inventors, faced this problem squarely, but did not resolve it:

To put the matter concretely: the next time that someone invents, as Whittle invented, a new type of engine, is there any way in which the individual inventor can be spared the neglect, discouragement, or active obstruction which was Whittle's experience. The answer may be no. It may be that, clumsy and wasteful as the process seems, no more effective way can be found of separating wheat from chaff among individual inventors than to submit them to this kind of rough jostling. For, it may well be argued, if there were no method for enforcing standards and sidetracking the charlatans, we would be overrun by a jungle of cranky ideas. [177]

Other circumstances besides the obstacles faced by private inventors and small companies may also give rise to solar technology underutilization. The research and development facilities of larger corporations produce many innovations, patented and otherwise, which never reach the stage of commercialization [178]. A particular invention may seem to the company to be only a second-best solution to the problem, as compared with another method already in use or recently discovered. Similarly, an invention may generate savings that are too insignificant to justify the enormous expense of adapting present facilities to the innovation. The company's management structure, in which each decision-making level is held accountable to a higher level, may tend to discourage seemingly risky new approaches even when developed within the company. In 
each case, another company might find such unused innovation worth developing. In these situations, licensing may still not be used due to the failure of the enterprise to designate any particular person whose duties include taking the initiative to explore licensing, as well as to an understandable reluctance to license, thereby aiding potential or actual competitors.

It is easy to imagine situations in which important technology fails to reach the public. One company might produce some results in the area of photovoltaics and then abandon the project for fear the entire area is still too doubtful to justify major new investment. Another firm may market a collector using certain materials and design features, while alternative approaches that they have developed remain unexploited.

But it is unnecessary to conjure up such hypothetical situations. Inventors and small companies in the solar industry are struggling daily with licensing-related problems. Several examples illustrate such problems within a 20-mile radius of the Solur Energy Reseurch Institute.

One example is a small firm, with about 12 employees, in the Denver area. The company designs, manufactures, and sells solar collectors and solar greenhouses. Design patents cover the greenhouses. Because shipping greenhouses is impractical, the Denver company had licensed a business in another state to construct and sell the greenhouses in the other business' area. Differences had arisen, however, about the respective rights and duties of the parties under the agreement. The Denver firm was dissatisfied with the other company's performance and wished to escape from the arrangement entirely, while the other firm was threatening to sue. To make matters worse, the Denver firm was hoping to raise capital through a public stock offering, but ongoing litigation would make the initial stock offering less attractive to potential investors. Inexperience and lack of sound advice had caused these parties to enter an agreement with other parties who were not suited to their particular needs, and to fail to provide contractually for solutions to the problems they encountered later. For a struggling young company, such mistakes can be fatal; hopefully, these particular pioneer solar entrepreneurs will survive and learn from their errors.

Another example reflects the opposite problem-when licensing is not used at all. At a nearby university, a Professor of Physics with an impressive record of inventions and publications in the nuclear area had devoted much time, including a year-long leave of absence, to designing technology for heating buildings. He had patented a solar collector and had patents pending on wood-burning stove designs. Various friends and associates had pooled their funds and there had been an attempt to produce and market these devices. The ideas are novel and may yet prove important. However, poor business judgment caused rapid depletion of the funds and prospects for raising more appear dim. Significantly, no one had considered trying to license out the rights to any of these devices; at present, these potential innovations are competing with lawn mowers for space in the inventor's garage.

In our free market economy, much inefficiency and waste is possible before a technological innovation reaches the public. Inventors struggle, ideas are ignored, and actual social needs remain unfulfilled for years. But this inefficiency can ordinarily be justified, as it was by Jewkes [179], by applying a simple cost-benefit analysis to the alternatives. The cost of streamlining the process of testing and exploiting innovation seems to exceed the expected benefits, such as decreasing the time lag between invention and commercialization. 
This cost-benefit analysis should yield to a different assessment, however, in the case of solar energy. The urgency of the energy crisis demands effective solutions soon. The Federal Government is spending hundreds of millions of dollars on energy-related research. It hardly makes sense to allow technology which already exists to languish. The recommendations that follow are directed at providing, or at least beginning to provide, solutions to the problem of underutilized technology. Essentially, it is suggested that SERI (another agency or an intra-industry body might be just as appropriate) provide information and consultation services that could eliminate at least some of the most obtrusive barriers to licensing activity. 


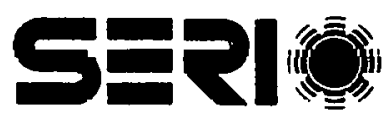




\section{SECTION 5.0}

\section{CONCLUSIONS AND RECOMMENDATIONS}

On the basis of the information presented in this paper, the following conclusions are reached:

- Licensing is an important means for making available technological advances that might not otherwise reach the public.

- Licensing can play an important role in the development of the solar industry.

- At present, use of licensing by small companies and private inventors is ha mpered by a variety of factors, including:

- lack of practical knowledge about the legal and financial aspects of licensing;

- the expense and relative unavailability of competent advice; and

- the relative lack of interest by large corporations in exploiting ideas developed by private inventors.

As a result, the following recommendations are made:

- Further detailed study should be made of current licensing practices in the solar industry to see if distinct patterns of use emerge according to size of company or other factors, and to define more clearly specific problem areas.

- An information program should be established to provide inventors and small companies with basic knowledge about licensing, including, but not limited to:

- the basics of intellectual property law;

- the basics of licensing law;

- common legal and practical pitfalls of licensing arrangements;

- where to obtain legal and business advice; and

- how to make contacts within the solar industry for the purpose of initiating licensing arrangements.

Such a program could include pamphlets on relevant subjects, and/or staff persons available for consultation.

- Alternatively, an expanded information/consultation program to actively:

- establish a network of contacts between potential licensees and licensors in the solar industry;

- provide legal and business advice; 
- reach out to the solar industry, including large corporations, private inventors, and everything in between, in an active effort to encourage utilization of licensing; and

- otherwise seek to expedite the flow of technology and know-how within the solar energy industry. 


\section{SECTION 6.0}

\section{REPERENCES}

1. For an authoritative, but somewhat outdated, treatment of the various solar technologies, see Daniels, Farrington, Direct Use of the Sun's Energy (New York: Ballantine Books, 1964).

2. Bereny, Justin A., Survey of the Emerging Solar Energy Industry: 1977 Edition (Solar Energy Infor mation Services, 1977), p. 301.

3. Solar Energy Research, Development and Demonstration Act of 1974, 42 U.S.C. $\$$ 5551 et seq.; Federal Non-Nuclear Energy Research and Development Act of 1974, 42 U.S.C. $\$ 5902$ et seq.

4. Kayton, Irving, Introduction to Patents and Patent Practice (Washington D.C.: Patent Resources Institute, 1976), Vol. I 1-1.

5. 35 U.S.C. $\$ 154$.

6. 37 C.F.R. 1 et seq.

7. United States Constitution, Article I, Section 8, Clause 3.

8. 35 U.S.C. $\$ 112$.

9. 35 U.S.C. $\$ 112$.

10. 35 U.S.C. $\$ 113$.

11. 35 U.S.C. $\$ 115$.

12. 35 U.S.C. $\$ 41$.

13. 35 U.S.C. $\$ 101$.

14. The Supreme Court has insisted that these three requirements are mandated by the Constitution as well as by the statute. See e.g., Thompson v. Boisslier, 114 U.S. 1 (1884), in which the court declared: "The beneficiary must be an inventor and must have made a discovery .... it is not enough that a thing shall be new, in the sense that in the shape or form in which it is produced it shall not have been before known, and that it is useful, but it must under the Constitution and the statute, amount to an invention or discovery." 114 U.S. at 3.

15. 11 How. 248,52 U.S. 248 (1850).

16. 11 How. at 267, 52 U.S. 266.

17. Pearce v. Mulford, 102 U.S. 112, 118 (1880).

18. Cuno Engineering Corp. v. Automatic Devices Corp., 314 U.S. 84, 90-91 (1941).

19. 35 U.S.C. $\$ 103$.

20. Graham v. John Deere Co. of Kansas City, 383 U.S. 1 (1966).

21. 35 U.S.C.\$102.

22. For a discussion for the layperson of the kinds of records an inventor should keep, see An Introduction to Patents (New York: Bell Laboratories, Inc., 1956).

23. 35 U.S.C. $\$ 271$. 
24. 35 U.S.C. $\$ \$ 283,284$.

25. 35 U.S.C. $\$ 282$.

26. Scherer, F. M.; Industrial Market Structure and Economic Performance (Chicago: Rand McNally \& Company, 1970), p. 391.

27. Reynolds, Edward, "The Standard of Invention is the Patent Office," in Ball, William, ed., Dynamics of the Patent System (New York: Central Book Company, 1960), p. 15.

28. Nash, Bernard, "Remarks Before the Industrial Research Institute," 59 JP0S 143, 146 (March 1977).

29. Markey, Howard T., "The Status of the U.S. Patent System-Sans Myth, Sans Fiction," 59 JPUS 164, 167 (March 1977).

30. 74 Am. Jur. 2d 704. See also $15 \$ 1127$ (The Lanham Act).

31. Beechnut Co. v. Lorillard Co., 273 U.S. 629, 632 (1927).

32. The Trademark Cases, 100 U.S. 82,92 (1879).

33. Article I, Section 8, Clause 8.

34. Trademark Cases, 100 U.S. at 94.

35. 15 U.S.C. $\$ 1127$.

36. Article I, Section 8, Clause 3.

37. The federal statute states that its intent is "to regulate commerces within the control of Congress by making actionable the decentive and misleading use of marks in such commerce; to protect registered marks used in such commerce from interference by State, or territorial legislation; to protect persons engaged in such commerce against unfair competition; to prevent fraud and deception in such commerce by the use of reproductions, copies, counterfeits, or colorable imitations of registered marks . ..." 15 U.S.C. $\$ 1127$.

38. United Drug Co. v. Theodore Rectanus Co., 248 U.S. 90, 97 (1918).

39. Armstrong Paint \& Varnish Works v. Nu-Enamel Corp., 305 U.S. 315, reh.den.305 U.S. 675 (1939).

40. 15 U.S.C. $\$ 1072$.

41. See e.g., Miss Universe, Inc. v. Patricelli, 408 F.2d 506, 509 (2nd Cir. 1969) (Strong presumption of validity given to Federal registration).

42. Columbia Mill Co. v. Alcorn, 150 U.S. 460, 463-4 (1893).

43. United Drug Co, v. Theodore Rectanus Co., 248 U.S. at 100.

44. Amoskeag Mfg. Co. v. Tranier, 101 U.S. 51,53 (1879).

45. Sears, Roebuck \& Co. v. Stiffel Company, 376 U.S. 225, reh. den. 376 U.S. 973 (1964); Compco Corp. v. Day-Brite Lighting, Inc., 376 U.S. 234, reh. den.377 U.S. 913 (1964).

46. Compco, 376 U.S. at 238.

47. 15 U.S.C. $\$ 1127$.

48. Kidd v. Johnson, 100 U.S. 617,620 (1879). 
49. For information on manufacturers of collectors and other equipment, see Bereny, Survey of the Emerging Solar Energy Industry.

50. 35 U.S.C. $\$ 103$. See text supra at notes 13-29.

51. See text infra. at note 70 , et seq. for discussion of the reasons behind decisions not to seek patents of patentable information.

52. See for example Costner, Thomas E., and Harold Einhorn, Patent Licensing Transactions, $\$ 1.06$, Note 2 (1977 edition); and Milgrim, Roger, Trade Secrets, $\$ 2.01$ (1978 edition).

53. Restatement of Torts, $\$ 757$, Comment b (1939).

54. Cf. the distinction between "proprietary know-how" and "non-proprietary knowhow" in Eckstrom, Lawrence J., Licensing in Foreign and Domestic Operations; $\$ 4.01$ (1977 edition). Also see Reynolds Metals Co. v. Skinner, 166 F.2d 66, 75, 76 (1948).

55. Milgrim Roger, "Trade Secrets and Know-How as the Subject Matter of a License," in Milgrim, ed., Proceedings of the First Annual Meeting of the Licensing Law and Business Institute. (1970).

56. For a compilation of statutes and cases, see Milgrim, Trade Secrets, $\$ 3.01$, n.3.

57. Id. $\$ 4.03$.

58. Id. $\$ 1.10$.

59. Id. $\$ 7.04[1]$.

60. Id. $\$ 8.03[1][6]$.

61. See for example N.J. Rev. Stat. $\$ 2$ A.-119-5.1 (Cum. Supp. 1965); California Code Annu., Penal Code $\$ 499$ c; and Smith-Hurd Illinois Anno. Stats., C.38 \$\$ 15 et seq.

62. Speedry Chem. Prods., Inc. v. Carter's Ink Co., 306 F.2d 328 (2d Cir. 1962).

63. See e.g., Sinclair v. Aquarius Electronics, Inc., 42 Cal. App. 3d 216, 116 Cal. Rptr. 654, 184, U.S.P.Q. 682, 684 (1st Dist. 1974).

64. Smith v. Dravo Corp., 203 F.2d 369, 97 U.S.P.Q. 98 (7th Cir. 1953).

65. See e.g., Vulcan Detinning Co. v. American Can Co., 72 N.J. Eq. 387, 67 A.339 (1907).

66. Universal Sav. Co. v. American Can Co., 72 N.J. Eq. 387, 67 A.339 (1907).

67. See e.g., A. O. Smith Corp. v. Petroleum Iron Works Co., 73 F.2d 531 (6th Cir. 1934), mfd'd, 74 F.2d 934 (6th Cir. 1935).

68. See e.g., Reynolds Metals v. Skinner, 166 F.2d 66 (6th Cir. 1948); Hooker Chemical Corp. v. Velsicol Chemical Corp., 275F. Supp. 412 (W.O. Tenn., 1964).

69. 35 U.S.C. 284, 285; Monoligh Portland Midwest Co. v. Kaiser Aluminum \& Chem. Corp., 407 F.2d 288 (9th Cir. 1969).

70. Sperber, Philip, Intellectual Property Management: Law-Business-Strategy, (1978 edition), $\$ 3.06$, $\mathrm{pp}: 3-39,3-40$.

71. Lear, Incorporated v. Adkins, 395 U.S. 65 (1969).

72. Scc text gupra. at note 28 et seg. 
73. In 1974, The Supreme Court specifically ruled that trade secrets could be licensed and royalties collected, in Kewanee Oil v. Bicron Corp., 416 U.S. 470 (1974).

74. See text supra at note 63 et seq.

75. General Information Concerning. Patents, (Washington, D.C.: U.S. Department of Commerce, Patent Office, 1965), p. 2.

76. 17 U.S.C. $102(a)$.

77. 17 U.S.C. $\$ 102(b)$; See Welles v. Columbia Broadcasting System, Inc., 308 F.2d 810 (9th Cir., 1962); Uneeda Doll Co. v. P\&M Doll Co., 353 F.2d 788 (2d Cir. 1965).

78. 17 U.S. 1 et seq.

79. See Brennan, Thomas, "Legislative History and Chapter 1 of S.22," in The Complete Guide to the New Copyright Law (New York Law School: 1977).

80. 18 Am. Jur. 2d 311 .

81. 17 U.S.C. $\$ 301$.

82. 17 U.S.C. \$ 104.

83. 17 U.S.C. $\$ 106$.

84. 17 U.S.C. \$ 302(a).

85. 17 U.S.C. $\$ \$ 303,304$.

86. 17 U.S.C. $\$ 302(c)$.

87. 17 U.S.C. \$ 302(c).

88. 17 U.S.C. $\$ 401$.

89. 17 U.S.C. $\$ 405$.

90. 17 U.S.C. $\$ 405$.

91. 17 U.S.C. $\$ 407$.(c).

92. 17 U.S.C. $\$ 408$.

93. 17 U.S.C. $\$ 408(\mathrm{c})$.

94. 17 U.S.C. $\$ 411$.

95. 17 U.S.C. \$ 502.

96. 17 U.S.C. S 503.

97. 17 U.S.C. $\$ 504(\mathrm{a})$, (b).

98. 17 U.S.C. $\$ 504(\mathrm{c})$,

99. 17 U.S.C. $\$ 506$.

100. For further discussion, see Milgrim, Trade Secrets, $\$ 2.06 \mathrm{~A}$.

101. Volume I, I. Kayton, Introduction to Patents and Patent Practice, 1-4 (1976).

102. G. A. Bloxam, Licensing Rights in Technology: A Legal Guide for Managers in Negotiation, 1 (1972).

103. 35 U.S.C. $\$ 261$. 
104. "A legal assignment is a transfer or setting over of property, or of some right or interest therein, from one person to another, and unless in some way qualified, it is properly the transfer of one's whole interest in an estate, or chattel, or other thing." 6 Am. Jur. 2d 185.

105. 138 U.S. 252 (1891).

106. Id. at 255 .

107. Water man v. Mackenzie, 138 U.S. 252 (1891); Kenyon v. Automatic Instrument Co., 160 F.2d 878 (6th Cir. 1947); Heywood-Wakefield Co. v. Small, 96 F.2d 496 (1st Cir. 1938); Six Wheel Comp. v. Sterling Motor Truck Co., 50 F.2d 568 (9th Cir. 1931); Evans v. Kavanagh, 86 F.Supp. 535 (E.D. Mich. 1949), aff'd 188 F.2d 234 (6th Cir. 1951).

108. Water man v. Mackenzie, 138 U.S. at 255.

109. Adams v. Burke, 84 U.S. 700 (1873).

110. Water man v. Mackenzie, 138 U.S. at 255.

111. Kewanee Oil v. Bicron Corp., 416 U.S. 470, 181 U.S.P.Q. 673 (1974), rev'g 478 F.2d 1074, 178 U.S.P.Q. 3 (6th Cir. 1971).

112. Von Brimer v. Whirlpool Corp., 180 U.S.P.Q. 182 (N.D. Cal. 1973); Discovery Rights, Inc. v. Avon Prods. Inc., 182 U.S.P.Q. 396 (N.D. Ill. 1974); Newton Insert Co. et al. v. Comm'r Internal Revenue, 181 U.S.P.Q. 765 (U.S.T.C. 1974).

113. See e.g., 135 U.S.C. $\$ 26 \mathrm{l}$, which expressly authorizes exclusive licensing of patents within territories.

114. Cutter Laboratories, Inc. v. Lyophile-Cryochem Corp., 179 F.2d 80 (9th Cir. 1949).

115. See e.g., Dynatech Corp. v. Frigitonics, 164 U.S.P.Q. 429 (E.D. La. 1970).

116. See e.g., American Tel. \& Tel. Co. v. Radio Audion Co., 284 Fed. 1020 (3d Cir. 1922).

117. 26 U.S.C. $\$ 1235($ a). Fawik v. Commissioner, 168 U.S.P.Q. 324 (6th Cir. 1971); Kirby v. United States, 191 F. Supp. 571 (S.D. Tex. 1960); Block v. United States, 200 F.2d 63 (2d Cir. 1952); Bannister v. United States, 262 F.2d 175 (5th Cir. 1958); Rollman v. Commissioner, 244- F.2d 634 (4th Cir. 1957); United States v. Carruthers, 219 F.2d 21 (9th Cir. 1955). It is generally held that "all substantial rights" is not the same standard as that established in Waterman v. Mackenzie to distinguish patent licenses from assignments. A major factor for the purposes of determining the appropriate tax status of the transaction is the extent of the exclusivity granted under the license. Obviously, the more exclusive the license, the more likely it is that the royalties will be considered capital gains.

118. St. Louis Standard Flushing Mach. Co. v. Sanitary Standard Flushing Mach. Co., 178 Fed. 923 (8th Cir. 1910).

119. De Forest Radio Telephone \& Telegraph Co. v. United States, 273 U.S. 236 (1927); Richmond Screw Anchor Co. v. Umbach, 173 F.2d 532, 80 U.S.P.Q. 531 (7th Cir. 1949).

120. Williston on Contracts $\$ 631$ (1961).

121. Corbin on Contracts $\$ 579$ (1960).

122. Hotcher v. Neon Prods., 163 F.2d 672, 75 U.S.P.Q. 108 (6th Cir. 1947); Taylor Gas Producer Co. v. Wood; 125 Fed. 337 (3d Cir. 1903). 
123. For a full listing, by state, see Restatement (Second) of Contracts Statutory Note, 414-419 (Tentative Drafts Nos. 1-7, 1973).

124. Schick Serv. Inc. v. Jones, 173 F.2d 969 (9th Cir. 1949).

125. I. L. Eckstrom, Licensing Foreign and Domestic Operations $\$ 1.03[3][e]$ (3d edition, 1977).

126. See e.g., Compton v. Metal Products, Inc., 172 U.S.P.Q. 263 (4th Cir. 1971) (patent misuse rendered agreement invalid).

127. Einhorn, Patent Licensing Transactions, 1.02[1] (1977 edition).

128. 273 U.S. 236 (1927).

129. Id. at 241 .

130. Robinson on Patents $\$ 834$, quoted in NeForest Radio Telephone \& Tclegraph Co. v. Radio Corporation of America, 9 F.2d 150 (D. Del. 1925).

131. See Popsicle Corp. v. Weiss, 40 F.2d 301 (S.D. N.Y. 1929).

132. United States v. Univis, Inc., 316 U.S. 241,51 U.S.P.Q. 113 (1941).

133. See Cold Metal Process Republic Steel Corp., 109 U.S.P.Q. 448 (6th Cir. 1956).

134. See e.g., Waterman v. Mackenzie, 138 U.S. 252, 256 (1891).

135. See e.g., Henry J. Kaiser Co. v. MeLouth Steel Corp., 175 F.Supp. 743 (E.D. Mich. 1959).

136. See Turner, "Antitrust Enforcement Policy," 29 A.B.A. Antitrust Section Rep. 187 (1965).

137. See e.g., Transparent Wrap Mach. Corp. v. Stokes \& Smith Co., 329 U.S. 637, 72 U.S.P.Q. 148 (1947); United States v. General Electric Co., 115 F.Supp. 835 (D.N.J. 1953).

138. See discussion supra at note 25 et seg. Also see, De Forest Telephone \& Telegraph Co. v. Marconi Wireless Telegraph Co., 243 Fed. 560 (2d Cir. 1917); Smith v. Nichols, 88 U.S. 112 (1874); In re Heinle, 145 U.S.P.Q. 131 (C.C.P.A. 1965).

139. United States v. Singer Mfg. Co., 374 U.S. 174, 137 U.S.P.Q. 808 (1963).

140. See Standard Oil Co. of Indiana v. United States, 283 U.S. 163, 9 U.S.P.Q. 6 (1931).

141. See e.g., Morton Salt Ço. v. Suppiger, 314 U.S. 488, 492, 493 (1812).

142. Brulotte v. Thys Co., 379 U.S. 29, 143 U.S.P.Q. 654 (1954).

143. For a forceful argument that agreements should be enforeed, even when the secret becomes public knowledge, see Milgrim, "Sears to Lear to Painton: of Whales and Other Matters," 46 N.Y.U.L. Rev. 17, 30-34. A case that apparently follows Milgrim's reasoning is Sinclair v. Aquarius Electronics, Inc., 42 Cal. App. 3d 216, 116 Cal. Rptr. 654 (Ct. App. 1974).

144. Adams v. Burke, 84 U.S. 700 (1873).

145. 304 U.S. 175, 37 U.S.P.Q. 357 (1938). .

146. 35 U.S.C. $\$ 261$.

147. Continental Paper Bag v. Eastern Paper Bag Co., 210 U.S. 405 (1908).

148. See generally 15 U.S.C. $\$ \$ 1$ et seq. (The Sherman Act); 15 U.S.C. $\$ \$ 12$ et seq. (The Clayton Act). 
149. City of Milwaukee v. Activated Sludge, 69 F.2d 577, 21 U.S.P.Q. 69 (7th Cir. 1934).

150. Appliance Corp. v. Speed Queen Corp., 89 U.S.P.Q. 1 (7th Cir. 1951 ).

151. See Kool Vent Metal Awning Corp. v. Bottom, 98 U.S.P.Q. 371 (8th Cir. 1953).

152. See Hazeltine Research, Inc. v. DuWald Radio Mfg. Corp., 79 U.S.P.Q. 446 (N.Y. Sup. Ct. 1948).

153. Eckstrom, Licensing in Foreign and Domestic Operations, $\$ 1.05$, atn. 6 .

154. For the statutory requirements, see 35 U.S.C. $\$ 287$.

155. Id.

156. Automatic Radio Manufacturing Co. v. Hazeltine Research, Inc., 339 U.S. 827,836 (1950).

157. 395 U.S. 653 (1969).

158. 395 U.S. at 670 .

159. 395 U.S. at 671 .

160. See e.g., St. Regis Paper Co. v. Royal Indus., 186 U.S.P.Q. 83 (S.D. Cal. 1974).

161. 402 U.S. 313 (1971).

162. For a more detailed list of factors prompting licensing agreements in foreign trade, see I. Eckstrom, Licensing in Foreign and Domestic Operations, $\$ 1.07[6]$, (1977).

163. See generally W. Bowman, Jr., Patent and Antitrust Law (1973).

164. 395 U.S. 653 (1969).

165. K. Norris and J. Vaizey, The Economics of Research and Technology, 78 (1973).

166. See A. Ezra, "Technology Utilization: Incentives and Solar Energy," in Science, Volume 187, \#4178 (February 28, 1975); W. Thomas, A. Miller, R. $\overline{R o b b i n s, ~}$ Overcoming Legal Uncertainties About Use of Solar Energy Systems, 13 (1978); P. Sperber, "Government Contracting: Perpetuating the Energy Crisis, "62 A.B.A.J. 1301-1304; and "Interim Policy Options for Commercialization of Solar Heating and Cooling Systems," ERDA 77-62.

167. A. Brown, "Invention and Innovation-What's Ahead," Les Nouvelles, Vol. VI, \#5, reprinted in The Law and Business of Licensing, $1,445$.

168. C. Gosline, "Doing Something with Really New Ideas," Les Nouvelles, Vol. V, \#5, reprinted in The Law and Business of Licensing, I, 427.

169. Brown, "Invention and Innovation," 454.

170. T. Levitt, "Yes, Throw Money at Problems," New York Times, April 28, 1978.

171. R. Miller, Legal Aspects of Technology Utilization, 7 (1977).

172. J. Jewkes, D. Sawers, R. Stillerman, Thc Sources of Invention, 82 (1859).

173. For a more detailed discussion of these resources, including names and addresses, see P. C. Hereld, "Idea Sources in New Product .Development," Les Nouvelles, Vol. 4, \#4, reprinted in Law and Business of Licensing, I, 363.

174. See Bereny, Survey of the Emerging Solar Energy Industry (1977).

175. See Jewkes, 314-321; See also, Sir Frank Whittle, Jet. The Story of a Pioneer (1953). 
176. See I. Kayton 1-4, 1-5.

177. Jewkes, 250-251.

178. See W. Pinsak, "Obtaining Undeveloped Patented Inventions of Large Companies," in The Law and Business of Licensing, Vol. I.

179. See above at notes 172 and 177 . 


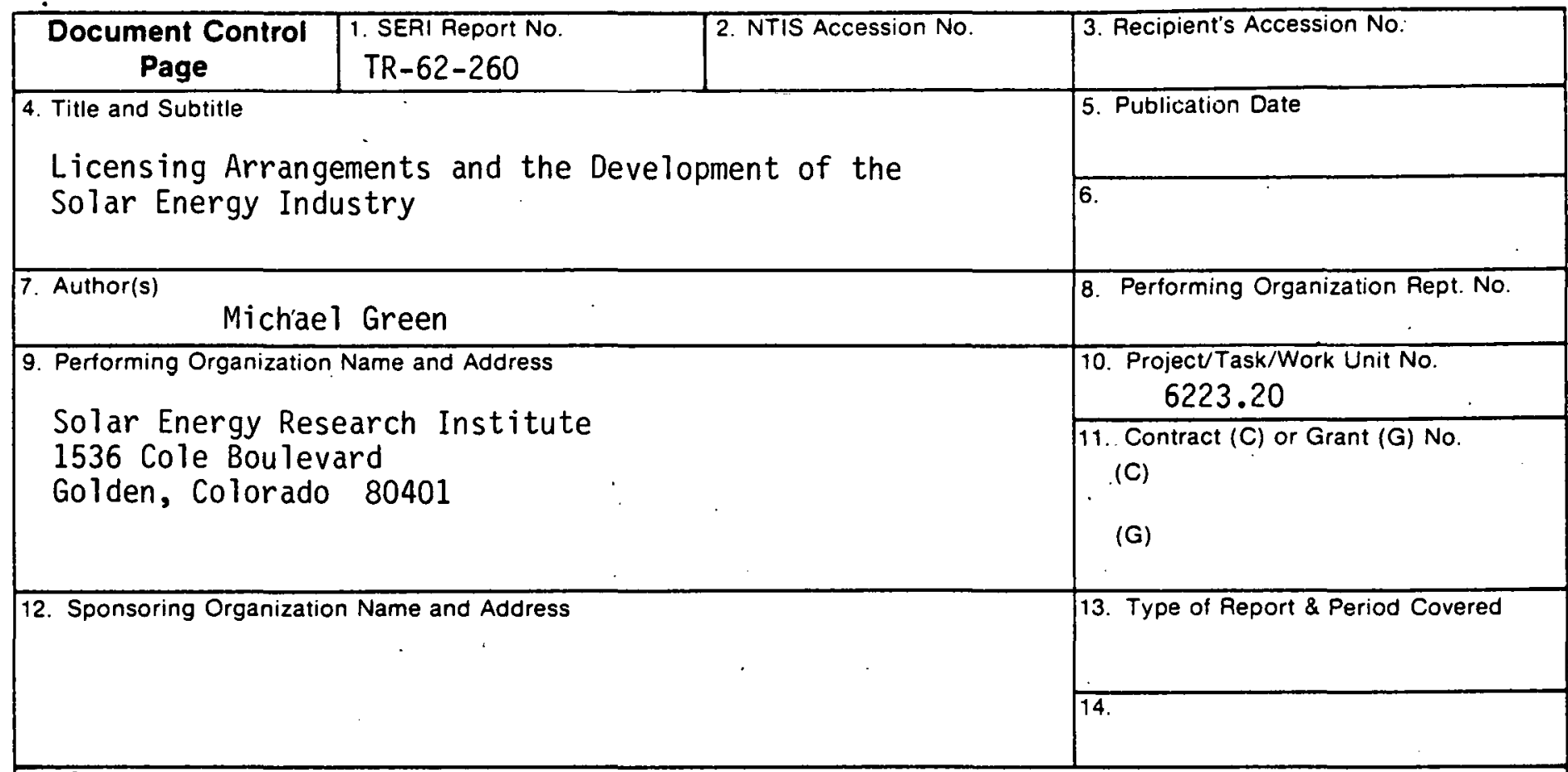

15. Supplementary Notes

16. Abstract (Limit: 200 words)

This paper explores the process by which solar technology and information related to solar technology are transferred within industry. The legal aspects of 1 icensing are examined, and the advantages and disadvantages of licensing from the point of view of potential licensees and licensors are described. Society, as a whole, often stands to benefit from licensing, because licensing creates greater efficiencies and increases the number of goods produced. Sometimes licensing is the only means by which a useful solar innovation can reach the marketplace. However, certain barriers impede the full utilization of licensing for solar inventions and technologies. Some barriers relate to the sizes of the enterprises involved. Small companies may lack the experience and knowledge to engage in the licensing process. 'Large companies tend to prefer to exploit their own ideas, or those developed by corporations of equivalent size. These barriers may be especially significant for the solar industry, in which many small actors are involved. It would be useful for a program to provide information about licensing to relevant actors in the solar industry. Such a program might improve the present situation, by informing those in the business of commercializing solar technologies about how best to exploit current federal, state, and customary licensing schemes.

17. Document Analysis

a. Descriptors

b. Identifiers/Open-Ended Terms

c. UC Categories

$59,60,61,62,63,64$

19. No. of Pages

44

20. Price 